\title{
News production by machines and ethics: possible implications
}

Lucas Vieira de Araújo 


\title{
News production by machines and ethics: possible implications
}

\author{
Lucas Vieira de Araújo, Methodist University of São Paulo
}

\begin{abstract}
This article seeks to question the production of news by machines in the light of journalistic ethics. Justified such study by the importance of the issue for journalism, as well as to broaden the debate on this issue in Brazil. The methodology was an exploratory research from interdisciplinary bibliography in order to carry out a theoretical discussion. Among the results, we envision is a certain incompatibility robots to exercise ethics, given its original limitations.
\end{abstract}

\section{Index Terms - Ethics, News, Machines, Journalism.}

\section{INTRODUCTION}

$\mathrm{J}$ OURNALISM has taken an important space in society for many years. Since the emergence of the first mass vehicles in the 19th centrury, the press performs a fundamental work to the democracy consolidation. In Brazil case, the emphasis is over the period of military dictatorship, from 1964 to 1984, when the repression against the journalistic work was more accentuated. Countless authors such as Kushnir (2004) [13] and Markun (2005) [15], with several academic papers, got down to the issue of brutality of the totalitarian regime and how much the resistance of some jornalists was essential to the downfall of the military from power and the return of the popular will on choosing the rulers.

However now, a day's journalism has been suffering questionings not only about the shifts in form, technique and productions of the news but also on its own future of the practice of social mediation. It was what made it possible for one of the most striking changes on journalism history: the use of machines on the news production For being a recent reality, this fact still generates controversy and a lot of doubts. Among them, if there are limits in this relationship, if the journalism practiced by a machine has the same value as made by a man and if that is ethical. This article does not have the expectation to respond satisfactorily to all these questions, but it aims to shed lights on some issues. To accomplish these discussions, this text will make use of the fundamental contributions of the scientists like Turing (1948) [20], Von Neumann (2006) [16], Wiener (1950) [21], and authors such as Gleick (2013) [11], Abbagnano (2007) [3], Bucci (2000) [5], Abramo (1988) [4], Rachels (2004) [18] and Allhoff (2007) [2]. This study is characterized by a theoreticalexploratory research, which saw an epistemological discussion on ethics and journalism.

\section{THEORETICAL Framework AND Discution}

\section{A. Ethics}

Ethics is the Conduct Sciences that discusses how the man relates to the society. Then it studies the values and principles of human behavior. The etymologycal word formation leads to two lines of ethics study. The first, called philosophic has a normative character and tries to stablish the universally valid principles for a good life in society. About it, we discuss an ideal universal moral. The second line of study, called scientific ethics, has explanatory character and tries to understand the historical morals on a reflection about the habits-. At this point arises the morals study (RACHELS, 2004) [18].

Bucci (2000) [5] complements the idea of two facets of ethics that one sits on an individual and its conduct, and the other on society. After a brief explanation of the theoretical bases of the two chains, differentiating the normative ethics, which he attributed to Kant the greatest exponent, of the more general ethics, whose one of the representatives would be Espinosa, Bucci argues that the way of acting of each person will determine the ethical behaviour. Abbagnano's dictionary of philosophy (2007) [3] summarizes ethics, much like a synthetic science of conduct, which would be guided by standards derived from the man himself, the result of his rationality, or precepts of which he obeys. Japiassú and Marcondes (2001) [12], however, address the ethics under a more practical bias. . The authors stated that the ethics does not approach the morals as the latter would be in charge of creating regulations. For them, while ethics would be in a more phylosophic-reflexive level, moral would deal with the day by day dilemmas faced by the man. Thus, the authors approach the utilitarian ethics or applied ethics to journalism.

Bucci has a very critical stance in relation to the role of the mass media, preponderantly to Rede Globo de Televisão. Stance corroborated by a significant share of the Academy. Hegemony and domination on the part of this debate, the professor argues that since the Universal Declaration of human rights, 1948, there is the indefeasible right to freedom of opinion and expression. The declaration, along with the article five from the Constitution of Brazil provides broad and unrestricted access to information. In this way, the media have an obligation to serve the public with fairness and accountability, virtues that would help the exercise of ethics of the companies and professionals who work for them. The former Ethics Carlos Alberto Di Franco makes passionate

Methodist University of São Paulo, São Bernardo do Campo, Brazil (professorlucasaraujo@gmail.com).
Article submitted on June 17, 2016. This work was supported in part by Capes (Personal Improvement Coordination), an agency of the Ministry of Education.

L. V. Araújo is a student of the Graduate Program, Level $\mathrm{PhD}$, of the 
defense of the quest for profit on the part of the communication companies and heavily criticizes the ethics scholars above business interests. Di Franco reverses the order by stating: "making money with information is an offence. It is an ethical duty "(1995, p. 35) [7]. However, just after he adds: "I am not, obviously, defending an utilitarian ethic. It has a value in itself and should be practiced regardless of profit. However, ethics and profit, in the media, should not be antagonistic realities "(1995, p. 35) [7].

The code of ethics of Brazilian Journalists is definite to treat possible interference in the production of news with disrespect. At the very first article the code says "access to public information is a right inherent in the life condition in society, which cannot be prevented by any kind of interest" (CÓDIGO DE ÉTICA, 1987) [6]. Another defender of ethics is the respected journalist Cláudio Abramo. He doesn't make a distinction between the ethics of the company and the employee. For him, there is the joiner ethics. Abramo confesses a deep taste for joinery and states that there are not two different ways to act when it comes to ethics. On the contrary, for him it is erroneous to expect a different conduct just because the person is a journalist, since there is no difference between the professional who produces news and citizen who reads news. "In journalism, the boundary between the professional as a citizen and as an employee is the same in any other profession. (...) The ethics of a journalist's ethics. What is bad for the citizen is bad for the journalist "(ABRAMO, 1988, p. 109) [4]

Abramo argues further that journalists should require ethics from the companies with regard to the processing with the class and not in relation to the public reader, viewer or listener. Totally contrasting opinion with Bucci, which calls it "alien" the posture of many journalists who refuse to discuss the media's modus operandi. "It's like the press proclaiming: my job is to inform the public, but my values are not in dispute, my methods of account of anyone else - they are good, correct and fair by definition" (2000, p. 39) [5]. It is interesting to note, however, that the writing and style Manual of the prestigious newspaper O Estado de S. Paulo does not mention how the journalists should proceed in their profession. The journal brings only the entry "internal Ethics" in the Manual, which brings several guidelines on standards of writing, for example, what is the correct way to a journalist refer to different newspaper O Estado (MARTINS FILHO, 1997) [14].

\section{B. Journalism and Machines}

Figure until recently common in science fiction movies or books, the machines are taking over more and more functions typically human. One is journalism (EMPRESA, 2012) [10]. A robot can be defined as an mechanical system integrated of rigid, articulated sets between themselves and claw or device specialized served to perform complex or high-risk activities for man in processes (ORTEGA; SPONG, 1989) [17]. Although it seems very far from the reality of the newsrooms, a lot of changes have been in progress. If in the industry, in General, the robot does not approach the intellectual work of producing a text, Ortega and Spong (1989) [17] feature the machine in a way closer to the daily life of a journalist. For them these objects are built to handle materials, parts, tools, or specialized devices through variable programmed motions for the performance of various tasks. This means that when a software produces a text from statistics collected during a football match, for example, is conducting a routine for which it was programmed by handling materials, in case the game numbers.

In this way, it is possible to have a glimpse_of the reasons why some companies are already adopting information producing machines in the production of news and why this is a very likely trend for the future. From the point of view of the management strategy for companies, is quite advantageous to replace human labor by machinery. The most visible is on high risk activities, preventing the real risk to the health of workers. However, in intellectual activities there are also several benefits, including lower costs and optimization of the production process. If until recently the employment of machinery was subject to the execution of specific tasks in the production process, such as painting or handling of objects, recently the using of robots moved also into intellectual works (TACHIZAWA et al., 2009) [19]. These, in turn, became ubiquitous in contemporary society, being one of the latest areas to step into journalism. For now, the machines are present, often through the production of textual reports, notably in the sport and economics editorials. 2011 dates the beginning of that process, but recently the practice has spread substantially

This practice has been raising heated debates between supporters and detractors of the practice. In the United States the blog Journalism in the Americas, from the University of Texas at Austin, brought up several clashes between researchers, journalists, politicians and legal experts on the ethics surrounding the use of remote devices for gathering information. A post in 2013 listed several initiatives that are academic debating new ways of doing journalism without human intervention. The Robotic Journalism Lab of the University of Nebraska-Lincoln's, for example, built unmanned aerial vehicles (UAV), known as drones, to perform reporting. The Missouri School of Journalism, information technology program at the University of Missouri, and the station of national public radio (NPR), KBIA launched a project in partnership that provides for the use of drones to carry out scientific investigative reports.

Proponents of these projects have argued that the use of these machines is something inexorable, reducing the media companies costs, already quite battered by internet competition. In addition, journalists and researchers defend the use of machines in locations of difficult access for humans, which would benefit with more complete reports. The detractors, as politicians and legal experts, are questioning this practice by the absence of legal provisions governing the sector. Without standards, they argue, these experiences should not be carried out (DYER, 2013) [9].

In Brazil the ethical discussions are also gaining prominence, especially, about the responsibility that a machine can take in certain circumstances. The portal Observatório da Imprensa, of remarkable credibility in the area, brought an article that uses a fact occurred in the United States to show the dilemmas that involve the participation of machines in the production of news (DIAKOPOULOS, 2014) [8]. According to the article, a robot created to detect scoops has replicated the information disclosed by a newspaper about the alleged death of a basketball player. Aware of the 
mistake, moments after the news was corrected by the original source, a human, but not by the robot, which is not scheduled for this kind of situation (ALBUQUERQUE, 2015) [1].

Though the practice of gathering information is increasingly recurrent and there is a defense around the freedom of the market, there are limits to certain practices. Allhoff (2007) [2] defends stricter measures to avoid excesses. He have greater concern about nanotechnology, however the Professor's questions can be extended to the use of machines in human activities in general. He states that there are two specific threats in relation to nano-robots that cannot be ignored, namely: a) they can be controlled by hostile entities of various types; b) they can self-replicate as autonomous bodies and cause immense damage to humanity. Despite of this field of scientific knowledge has not entered journalistic practices yet, this subject to the Professor is extremely relevant because it plays in ontological questions, due to the fact the man to be able to replicate and amplify feelings from others, but he still encounters ethical situations apparently without satisfactory answers.

Bucci (2000) [5] quotes some cases common at the journalist's day by day, in which a machine would hardly have conditions to replace a human being, even with all the precision and rationality that characterizes it. The Professor brings the example of a supposed radio reporter who would have witnessed a landslide upon returning home after a day's work. At the time it was raining hard and there were points of flooding. Yet as the fact in question, the journalist tries to narrate by cellphone on live the fact with very few impressions, but what is visible to your his and from his experience. In another situation, a fictional reporter interview a mayor accused of illicit enrichment. The politician uses the room to defend himself, but the journalist doesn't know to what extent the defense is true. In both examples, there is the possibility of transmitting parts of truth, since both the professionals would have little control over what is being said to the citizen.

In both situations, Bucci makes an elementary basic recommendation over a situation like this: do not lie. "The partial truth -is something the reporter mustn not do. All you can do is act according to their conscience, trying to look at the world with objectivity and not mask its limitations with arrogance of someone who sees everything "(2000, p. 88-89) [5]. In principle, it gives the impression that the professor's suggestion would be easily applied by a machine, since objectivity and precision are inherent characteristics of computers. However, it is to be questioned how far a robot could follow the recommendations from terms like partial truth, conscience and arrogance.

The way a machine operates is different from the way humans think. The eminent American scientist John Von Neumann published an important work on this aspect. In The computer and the brain, Neumann explained that the machines require calculations to perform the tasks required by humans, because the same generally relate to responses to Yes and no, that is, automated processes, in which abstract skills are required (2006, p. 108-109) [16]. Thus, in commented examples, if a computer had to say a partial truth, it simply would not say, because it was not programmed to do so. The problem would be even bigger if you consider the word consciousness. According to Abbagnano, consciousness is not only to be aware of what to do or not to do, as it comprises common sense. In terms of philosophy, consciousness presupposes: "a relation of the soul with itself, an intrinsic relationship to the man, "inner" or "spiritual", by which he can know himself in an immediate and privileged way, thus judge himself safely and infallibly (2007, p. 185) [3].

To enter on philosophical conception, so it would be impractical to think that the machine could be conscious, although significant advances have occurred in recent years in terms of speeding up information processing and storage capacity. Another great scholar of the machines and sharer of the same ideas as Von Neumann (2006) [16], contributed to the creation of the first computers was Alan Touring (1948). He was known for creating a mechanical and electrical device which performed mathematical calculations like few others in History. Called later as the Turing machine, the automaton was instrumental in World War II to decipher Nazi codes for the allied countries, along with a team which brought together chess players from champions up in crossword puzzles and puzzle solving. The importance of this work was so expressive that he kept secret for more than 30 years (GLEICK, 2013, p. 222) [11].

Turing wrote a seminal article for studies about computer machines in 1950 when he describes a game that would have aimed to find out if a machine can think. Denominated the Imitation game, the idea is to identify a human being between two people and a machine from questions and answers. The English researcher carries out a few categorical conclusions in his article, but asks a question which can be understood as an answer: "they can't accomplish something that machines should be described as thinking, but that is very different than what a man does." (1950, p. 435) [20]. That is, it may be that the machines don't do exactly what a human being does when it comes to thinking, however, they can do something with similar mechanism which is not necessarily the same.

Throughout the article, including, Turing seeks to dispel myths around which orbit and probably still exist, many doubts. One of them was that thinking was an essentially human assignment, assigned by God (1950, p. 443) [20]. More than simply to reject them, Turing prophesied what today is fully noticeable: "at the end of the century, the use of words and polite general opinions will have changed so much that one will be able to speak of machines thinking without waiting to be challenged" (1950, p. 442) [20]. Turing's conclusions reinforce the impression that a machine could hardly stand on the ethical dilemmas suggested by Bucci, given the fact that the thinking of the machine is different from human. Norbert Wiener in Cybernetics and Society, says that the digital camera works from all or nothing and that "the sharpness of the decision between ' yes ' and ' no ' allows us to collect information in order to provide us one way to discriminate very small differences in very large quantities" (1950, p. 64) [21]. So, as vouched by Von Neumann, the human brain does not have the precision of a computing machine with regard to discern information in the midst of many others, but can Excel in certain tasks. "The deterioration of arithmetic was exchanged for an enhancement of logic" (2006, p. 113) [16], concluded Neumann.

The logic is essential for the pillars of journalism and 
ethics, as evidenced by Bucci in saying that "the ethics is in praxis. There is a harmony between the customs and the good conduct, as the ethics is not nor could be outside of customs "(2000, p. 17) [5]. If ethics lies in the acting of the journalist, it is essential the vision of life in society so it can exist. Being ethics dependent on external factors, it is improbable that a machine have sufficient external information to make a decision based on opinions of others. Or even more distant from the reality it would be to imagine that a robot would be able to interact with humans in such a way that you could understand their behavior and take a logical conclusion from hat. About the ability of the machine to learn with itself and with the environment, Wiener made an enlightening explanation: "You can build it with a statistical preference for a certain kind of behavior which, however, admits the possibility of another behavior; or, certain characteristics of this behavior can be rigid and unalterably determined" (1950, p. 175) [21].

Even if a robot can learn, this learning will be limited by statistics, that is, as probability factors because it is inherent in the automata mechanism guided by mathematical calculations as a way of learning. This would be the core to understand why a machine will hardly perform human functions, such as ethical decisions. Every form of knowledge of a robot is intrinsically linked to its mathematical Genesis, but human relations are not. As Wiener, "the greatest weakness of the machine - such weakness which saved us so far to be dominated by it-is that it can't still take into account the wide range of probabilities that characterizes the human situation" (1950, p. 178) [21]. In other words, it is unlikely that mathematical calculations can map the numerous human idiosyncrasies to the point of a machine make accurate decisions from there.

Neumann goes to the heart of this issue when he says about the language of the brain and the Mathematics language: "the nervous system is based on two types of communications: those that do not involve arithmetic formalisms and the ones that involve, that is, order communications (logic) and numbers communications (arithmetic). The first may be described as a language and the second as mathematics" (2006, p. 114) [16].

Being different from the way the brain understands numbers and orders, it is believed that an ethical decision probably is not going to be a part of the mathematical framework, as ethics concerns individual behavior in a social context. Soon, a machine designed to perform commands, even if it can learn from the environment, it is unable to draw up a reasoning at this level of complexity. In the words of Neumann, "when we talk about mathematics, we could be discussing a secondary language, built on primary language actually used by the central nervous system" (2006, p. 116) [16].

It is noteworthy that the "primary" and the "secondary" terms used by Von Neumann do not concern the order of importance, but the manner with which the processes take place in the human brain. It is also important to remember that the language does not represent necessarily the alphabet, but the drafting logic which our brain emerges the world. Besides the human relations being fortuitous and unpredictable enough to practically makes it impossible precision in mathematical calculations of a machine, the calculation would not be the most appropriate way to make ethical decisions, since that the human brain performs better with the logic compared to mathematics.

In the dictates of Bucci, "journalism is conflict, and when there is no conflict in journalism, an alarm should go off. In fact, the ethics exists only because communication is a place of conflict "(2000, p. 11) [5]. So, being the conflict an opposition or fight of principles (ABBAGNANO, p. 173) [3] human brain finds it easier to deal with different situations that machine designed to make accurate decisions based on mathematical calculations.

\section{CONCLUSION}

The development of machinery and the subsequent use of it in the activities currently performed by humans is an inexorable reality. The dissemination, including in journalism, needs to be accompanied by discussions about the limits of use of drones, because it is clear that there are unquestionable differences towards humans, which implies aspects that cannot be disregarded. Ethics is one of those fields, because a robot will hardly be able to evaluate certain situations of the everyday life of a human journalist due to the own machine's atavistic conditions. Thus, it is important to evaluate which person could be held liable for Misconceptions or omissions of machines created to replace people in daily newsrooms, as companies have already begun this process.

This article does not want to create a stigmatized and prejudiced visionin relation to news producers robots. However, it is believed that it is necessary to point out certain aspects of this reality, such as the features and the inherent limitations of the machines, to be able to evaluate ways of dealing with journalistic ethical dilemmas. As this is a recent topic, the idea of this text is to start the debate in order to create deeper discussions

\section{REFERENCES}

[1] ALBUQUERQUE, S. "O Frankenstein cibernético". Observatório da Imprensa, São Paulo, 9 jun. 2015. Available: http://observatoriodaimprensa.com.br/e-noticias/o-frankensteincibernetico/.

[2] ALLHOFF, F. et al. "Nanoethics: The Ethical and Social Implications of Nanotechnology". New Jersey: John Wiley \& Sons, 2007, pp. 2575.

[3] ABBAgnanO, N. "Dicionário de filosofia". São Paulo: Martins Fontes, 2007, pp. 531-532.

[4] ABRAMO, C. "A regra do jogo: o journalism e a ética do marceneiro". São Paulo: Companhia das Letras, 1988, pp. 142-185.

[5] BUCCI, E. "Sobre ética e imprensa". São Paulo: Companhia das Letras, 2000, pp. 51-87.

[6] "CÓDIGO DE ÉTICA DO JORNALISTA BRASILEIRO". Rio de Janeiro: $1985 . \quad$ Available: http://www.fenaj.org.br/federacao/cometica/codigo de etica dos jor nalistas_brasileiros.pdf.

[7] DI FRANCO, C. A. “Jornalismo, ética e qualidade". Petrópolis: Vozes, 1995, pp. 32-43.

[8] DIAKOPOULOS, N. "Em busca da ética dos repórteres robôs". Observatório da Imprensa, São Paulo, 8 abr 2014, Available: http://observatoriodaimprensa.com.br/monitor-daimprensa/_ed793 em busca da etica dos reporteres robos/.

[9] DYER, Z. Drone reporting might be grounded before it gets a chance to take off". University of Texas, Austin, 25 fev. 2013. Available: https://knightcenter.utexas.edu/blog/00-13045-drone-reporting-mightbe-grounded-it-gets-chance-take.

[10] "EMPRESA americana cria robô-jornalista". Revista Superinteressante, São Paulo, ed. 308, ago 2012. Available: http://super.abril.com.br/tecnologia/empresa-americana-cria-robosjornalistas. 
[11] GLEICK, J. “A Informação: uma história, uma teoria, uma enxurrada”. São Paulo: Companhia das Letras, 2013, pp. 376-444.

[12] JAPIASSÚ, H.; MARCONDES, D. "Dicionário básico de filosofia". Rio de Janeiro: Jorge Zahar, 2001, pp. 333-334.

[13] KUSHNIR, B. "Cães de guarda: jornalistas e censores, do AI-5 à Constituição de 1988”. São Paulo: Boitempo Editorial, 2004, pp. 2944.

[14] MARTINS FILHO, E. L. "Manual de redação e estilo de O Estado de S. Paulo". São Paulo: O Estado de S. Paulo, 1997, pp. 78-99.

[15] MARKUN, P. “Meu amigo Vlado". Rio de Janeiro: Objetiva, 2005, pp. 65-102.

[16] NEUMANN, J. V. "O Computador e o Cérebro". Lisboa: Relógio D’Água, 2006, pp. 36-88.

[17] ORTEGA, R.; SPONG, M. W. "Adaptive motion control of rigid robots: A tutorial". Automatica, v. 25, n. 6, p. 877-888, 1989.

[18] RACHELS, J. "Elementos da filosofia moral”. Lisboa: Gradiva, 2004, pp. 22-74.

[19] TACHIZAWA, T. et al. "O fator humano no contexto da cadeia produtiva sustentável: uma análise da qualidade de vida baseada em pesquisa empírica". In: XII Simpósio de Administração da Produção, Logística e Operações Internacionais da Fundação Getúlio Vargas, 2009, São Paulo. Anais eletrônicos. Available: http://www.simpoi.fgvsp.br/arquivo/2009/artigos/E2009_T00025_PC N80703.pdf.

[20] TURING, A. M. “Computing Machinery and Intelligence”. Mind, New Series, vol. 59, n.236, p. 433-460, 1950

[21] WIENER, N. "Cibernética e sociedade: o uso humano de seres humanos”. São Paulo: Cultrix, 1950, pp. 15-64.

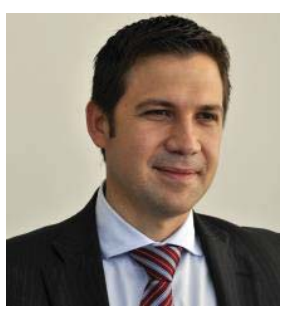

Lucas V. Araújo Degree in Journalism (1999), became master in Brazilian and Portuguese Literature (2008) and holds a doctorate in Communication from the Methodist University of São Paulo (2015). Capes scholarship. Currently conducts research on innovation in communications with an emphasis on the innovation ecosystem from accelerators, incubators and fostering innovation organizations.

He has served as several TV stations opened by Brazil, as an editor, reporter and Journalism Manager at Rede Globo, Rede Record and Rede Bandeirantes. He was also a Professor of undergraduate and graduate degrees in Journalism, Marketing and Advertising. Published book on the Paraná writer Domingos Pellegrini and articles on Data Journalism, Deep Web, new media and ethics in the use of data. 